\title{
Candidate Animal Disease Model of Elizabethkingia Spp. Infection in Humans, Based on the Systematic Pathology and Oxidative Damage Caused by $E$. miricola in Pelophylax nigromaculatus
}

\author{
Xiaoli Huang $\mathbb{D}^{1},{ }^{\text {Yang Feng }} \mathbb{D}^{1},{ }^{1}$ Hong Tang, ${ }^{2}$ Guanqing Xiong, ${ }^{1}$ Liangyu Li, ${ }^{2}$ Yucen Yang, \\ Kaiyu Wang, ${ }^{3}$ Ping Ouyang, ${ }^{3}$ Yi Geng $\mathbb{D},{ }^{3}$ Defang Chen $\mathbb{D}^{1},{ }^{1}$ and Shiyong Yang $\mathbb{D}^{1}$ \\ ${ }^{1}$ College of Animal Science and Technology, Sichuan Agricultural University, Chengdu, Sichuan 611130, China \\ ${ }^{2}$ Chengdu Academy of Agricultural and Forestry Sciences, Chengdu, Sichuan 611130, China \\ ${ }^{3}$ College of Veterinary Medicine, Sichuan Agricultural University, Chengdu, Sichuan 611130, China
}

Correspondence should be addressed to Xiaoli Huang; hxldyq@126.com and Shiyong Yang; yangshiyong@sicau.edu.cn

Received 2 March 2019; Accepted 14 August 2019; Published 18 September 2019

Academic Editor: Daniel Lopez-Malo

Copyright (c) 2019 Xiaoli Huang et al. This is an open access article distributed under the Creative Commons Attribution License, which permits unrestricted use, distribution, and reproduction in any medium, provided the original work is properly cited.

\begin{abstract}
Most species of the genus Elizabethkingia are pathogenic to humans and animals, most commonly causing meningitis. However, our understanding of the pathogenic mechanisms involved is poor and there have been few pathological studies of Elizabethkingia spp. in animals. To understand the host injury induced by Elizabethkingia spp., we established a model of E. miricola infection in the black-spotted frog (Pelophylax nigromaculatus). The systematic pathology in and oxidative damage in the infection model were investigated. Our results show that recently isolated E. miricola is a bacterium that mainly parasitizes the host brain and that neurogenic organs are the predominant sites of damage. Infection mainly manifested as severe brain abscesses, meningoencephalitis, necrotic spondylitis, and necrotic retinitis. The liver, spleen, kidney, gastrointestinal tract, and lung were also affected to varying degrees, with bacterial necrotic inflammation. P. nigromaculatus also suffered enormous damage to its oxidative system during E. miricola infection, which may have further aggravated its disease state. Our results provide a preliminary reference for the study and treatment of Elizabethkingia spp.-induced neurological diseases in animals.
\end{abstract}

\section{Introduction}

Elizabethkingia is a new genus of Gram-negative rod-shaped bacteria, described in 2005 , that were initially classified in the genus Chryseobacterium [1]. The genus includes four species, E. meningoseptica [2], E. miricola [3], E. anopheles [4], and E. endophytica [5], and almost all these species are strongly pathogenic to both humans and other animals [6-8]. Cases of human infection with Elizabethkingia spp. have been reported in the United States [9], England [10], Italy [11], Saudi Arabia [6], China [12], Central Africa [7], and India [13]. The disease is fatal in more than $50 \%$ of cases and can lead to meningitis, brain abscess, and other severe postinfection sequelae, including hydrocephalus, deafness, and developmental delay [14]. According to incomplete statistics, the mortality rate among people infected with Elizabethkingia spp. is 65\% according to the Centers for Disease Control and Prevention (https://www.cdc.gov/). Newborns and immunocompromised adults are most susceptible to infection with Elizabethkingia spp. [15-19] and are likely to suffer symptoms of irritability, poor feeding, seizure, cloudy cerebrospinal fluid, and polymorphonuclear pleocytosis [7]. These symptoms are often identified and treated as influenza or another disease, and this misdiagnosis, combined with the lack of an effective therapeutic regimen, makes patients almost 
impossible to cure after infection with Elizabethkingia spp., which ultimately leads to death. In general, meningoencephalitis is the commonest symptom of human Elizabethkingia spp. infection [6]. However, research into the characteristics and mechanisms of the damage caused by Elizabethkingia spp. in the host is extremely limited, as is the prevention and treatment of the associated diseases.

Interestingly, several studies have found that Elizabethkingia spp. can cause meningoencephalitis in frogs, including the African clawed frog (Xenopus laevis) [20], bullfrog (Rana catesbeiana Shaw) [21], leopard frog (Lithobates pipiens) [22], tiger frog (Rana rugulosa) [23], blackspotted frog (Pelophylax nigromaculata) [24], and spiny frog (Quasipaa spinosa) [25]. Infected frogs display severe neurological symptoms and meningoencephalitis similar to those in humans. Therefore, the frog may be a natural model organism for research into the meningoencephalitis induced by Elizabethkingia spp. in humans. Frogs also have the advantage of being more readily available for research than humans, which is an essential factor in the study of disease.

In August 2017, wryneck disease broke out on a blackspotted frog farm in Sichuan, China. We isolated three strains of bacteria from the diseased frogs and identified them as E. miricola. To systematically explore the mechanisms underlying the invasiveness and damage caused by Elizabethkingia spp. in animals, an Elizabethkingia spp.induced black-spotted frog infection model was established based on the strains isolated in the present study. The systematic pathology, the parasitized and damaged target $\operatorname{organ}(\mathrm{s})$, and the oxidative damage caused by the bacterium were investigated in the model. Our findings extend our understanding of the meningoencephalitis induced by Elizabethkingia spp. in both aquaculture organisms and humans and provide a reference for its prevention and treatment.

\section{Methods}

2.1. Bacterial Strain and Characteristics. The pathogenic strain used in this study was originally isolated from P. nigromaculatus with wryneck disease on a frog farm in Chongzhou, Sichuan, China, in 2017. The pathogen was isolated from the kidneys, livers, spleens, and brains of the diseased frogs on brain heart infusion (BHI) medium, and the colonies were picked for further purification. The isolated strain was cultured at $25^{\circ} \mathrm{C}$ for $18-24 \mathrm{~h}$.

The bacterial species was identified with standard biochemical assays (Tianhe, Hangzhou, China) and 16S rRNA sequencing (PCR primers: F, 5'-AGAGTTTGATCCTGGC TCAG- $3^{\prime}$ and R, 5'-GGCTACCTTGTTACGACTT- $3^{\prime}$ ). The amplified sequences were compared with the GenBank database (https://www.ncbi.nlm.nih.gov/) with a BLAST analysis. A homology analysis was performed with MEGA 7.0 and a phylogenetic analysis with the neighbor-joining method. The agar diffusion method (Kirby-Bauer method) was used to determine the sensitivity of the isolated strains to 11 antibiotics (Tianhe).
2.2. Animals. Three hundred healthy $P$. nigromaculatus (torso length $6 \pm 1.2 \mathrm{~cm}$, weight $35.5 \pm 3.5 \mathrm{~g}$ ) were purchased from a commercial frog farm (Meishan, Sichuan, China) and acclimated at our facility for 2 weeks. Healthy individuals were chosen for the experiment at the end of the acclimation period. The frogs were fed commercial pellets twice a day and maintained under a light: dark cycle of $12: 12 \mathrm{~h}$. The water temperature contained ammoniacal nitrogen and nitrite at $0-0.02 \mathrm{mg} / \mathrm{L}$, at a temperature of $22 \pm 2^{\circ} \mathrm{C}$ and $\mathrm{pH}$ of 7.0-7.5. The culture water was renewed every day, after pretreatment with an aeration process. All animal handling procedures were approved by the Animal Care and Use Committee of Sichuan Agricultural University (Chengdu, China) and followed the guidelines for animal experiments of Sichuan Agricultural University, under permit number 20181102002. All chemicals were of analytical grade or the highest grade available from local companies.

2.3. Establishment of the Meningitis Model. Responsive, robust, healthy frogs were selected for the experiment. The challenged frogs $(n=120)$ were divided into four groups-a control group (treated with $0.65 \%$ physiological saline) and three experimental groups: $1 \times 10^{8}$ group (treated with $1 \times 10^{8}$ colony-forming units $(\mathrm{CFU}) / \mathrm{mL}$ purified strain), $1 \times 10^{9}$ group (treated with $1 \times 10^{9} \mathrm{CFU} / \mathrm{mL}$ purified strain), and $1 \times 10^{10}$ group (treated with $1 \times 10^{10} \mathrm{CFU} / \mathrm{mL}$ purified strains). Each group included three parallel tanks. The purified strain $\left(1 \times 10^{8}, 1 \times 10^{9}\right.$, or $\left.1 \times 10^{10} \mathrm{CFU} / \mathrm{mL}\right)$ was injected intramuscularly into each frog in the experimental groups, and the frogs in the control group were injected with physiological saline. The entire experimental period was 14 days. All gross lesions and deaths in the frogs of each group were recorded daily, and the dead frogs were removed at that time. On day 14 after injection, the frogs in each group were euthanized with tricaine mesylate (MS-222) (Sigma-Aldrich, Beijing, China) and dissected for histopathological analysis and the analysis of viable counts, enzyme activity, and mRNA expression.

2.4. Detection of Target Organs with Major Lesions. Three frogs in each group were humanely euthanized with MS222. The skin, muscles, eyes, lung, brain, heart, liver, spleen, and kidneys were removed, fixed in neutral-buffered formalin, and dehydrated in ethanol. The tissues were trimmed into cassettes, dehydrated in graded ethanol solutions, cleared in xylene, and embedded in paraffin wax. Sections (3 $\mu \mathrm{m})$ were prepared for hematoxylin and eosin staining before a microscopic analysis (Nikon, Tokyo, Japan).

The degrees of hemorrhage, edema, deposits, hypertrophy, hyperplasia, atrophy, infiltration, and necrosis in the organs were evaluated according to the scoring system designed by Bernet et al. (Table 1) [26]. Every change was assessed with a score $(S)$ ranging from 0 to 6 , depending on the degree and extent of the change: (0) unchanged, (2) mild change, (4) moderate change, and (6) severe change (diffuse lesion). Intermediate values were also considered. The organ index $\left(I=\sum_{t} \sum_{\mathrm{alt}}\left[S \times \omega_{\mathrm{IF}}\right]\right)$ and total index $\left(I=\sum_{\mathrm{Org}} \sum_{t} \sum_{\mathrm{alt}}\left[S \times \omega_{\mathrm{IF}}\right]\right)$ of each experimental group were calculated in this study ( $\omega_{\mathrm{IF}}$ : importance factor). 
TABle 1: Histopathological assessment. An importance factor $\left(\omega_{\mathrm{IF}}\right)$, ranging from 1 to 3 , was assigned to every change $(1-$ minimal pathological importance: the lesion is easily reversible as exposure to irritants ends; 2-moderate pathological importance: the lesion is reversible in most cases if the stressor is neutralized; and 3-marked pathological importance: the lesion is generally irreversible, leading to partial or total loss of the organ function [26]).

\begin{tabular}{|c|c|c|c|}
\hline Organ (Org) & Functional unit of the tissue $(t)$ & Alteration (alt) & Importance factor $\left(\omega_{\mathrm{IF}}\right)$ \\
\hline Kidney & Tubule/glomerulus/interstitial tissue & & \\
\hline Liver & Liver tissue/interstitial tissue & Haemorrhage & 1 \\
\hline Heart & Epicardial/myocardium/cardiac chamber & Hyperaemia & \\
\hline Lung & Alveolar/capillaries & Edema & 1 \\
\hline Spleen & Interstitial tissue/sinusoid & Deposition & 1 \\
\hline Muscle & Muscle fiber/connective tissue & Hypertrophy & 1 \\
\hline Brain & Meninges/brain parenchyma & Hyperplasia & 2 \\
\hline Spine & Nerve tissue/muscle tissue/connective tissue & Atrophy & 2 \\
\hline Eye & Retina/cornea & Infiltration & 2 \\
\hline Stomach & Mucosa/smooth muscle layer & Necrosis & 3 \\
\hline Intestinal & Mucosa/lamina propria/smooth muscle layer & & \\
\hline
\end{tabular}

2.5. Ultrastructural Examination. The livers of three frogs from each group were sampled, immediately fixed in $2.5 \%$ glutaraldehyde, and postfixed in $2 \%$ veronal-acetatebuffered osmium tetroxide. After dehydration in graded alcohol, the samples were embedded in Araldite. The blocks were sectioned on a microtome with a glass knife. The sections (6.575 $\mu \mathrm{m}$ thick) were placed on uncoated copper grids, stained with uranyl acetate, and poststained with $0.2 \%$ lead citrate. The subcellular structures of the liver were examined with a Hitachi H-600 Transmission Electron Microscope (Hitachi, Tokyo, Japan).

2.6. Bacterial Colonization of Target Organs. Specific primers were designed to bind the $16 \mathrm{~S}$ rRNA sequence of E. miricola (F: $5^{\prime}$-CGAACTGCCATTGATACTG-3' and R: $5^{\prime}$-CGCT TAGTCTCTGAATCCTA- $3^{\prime}$ ). Bacteria were randomly isolated from frogs in the experimental groups and identified with PCR using the 16S-rRNA-specific primers. The PCR thermal cycling conditions were $3 \mathrm{~min}$ at $95^{\circ} \mathrm{C}$ followed by 30 cycles of $30 \mathrm{~s}$ at $95^{\circ} \mathrm{C}, 30 \mathrm{~s}$ at $60^{\circ} \mathrm{C}$, and $20 \mathrm{~s}$ at $72^{\circ} \mathrm{C}$. The PCR product was identified with $2 \%$ agarose electrophoresis (product size: $234 \mathrm{bp}$ ).

Three frogs in the $1 \times 10^{10}$ group were euthanized, and their livers, spleens, brains, lungs, kidneys, hearts, and muscles were dissected in a sterile environment. The live bacteria in the tissues were quantified with the viable count method. Briefly, the tissues were weighed in a sterile environment, homogenized in physiological saline (1:9), serially diluted, and spread on BHI medium. The colonies that appeared after incubation for $24 \mathrm{~h}$ at $25^{\circ} \mathrm{C}$ were counted to calculate the number of viable cells in the tissues.

2.7. Determination of Antioxidant Indices. The livers were removed from three frogs in each group and immediately homogenized in physiological saline at $4^{\circ} \mathrm{C}$. Each homogenate was centrifuged at $3500 \times \mathrm{g}$ at $4^{\circ} \mathrm{C}$, and the supernatant was used to detect different indicators. The total protein in the supernatant was determined with a quantitative total protein assay kit (A045-2; NJJCBIO, Nanjing, China). The total antioxidant capacity (TAC), the activity of superoxide dismutase (SOD), and malondialdehyde (MDA) were detected with biochemical kits (NJJCBIO, Nanjing, China), following the manufacturer's protocol.

2.8. Gene Expression of Antioxidants. The livers were removed from three frogs in each group, immediately placed in RNAiso Plus (TaKaRa, Japan), and stored at $-80^{\circ} \mathrm{C}$. The livers were then homogenized by crushing them, and the total RNA was isolated with the Simply P Total RNA Extraction Kit (Bioflux, China), according to the instruction of the manufacturer. The total RNA $(1 \mu \mathrm{g})$ was converted to firststrand cDNA with the PrimeScript ${ }^{\mathrm{TM}}$ RT Reagent Kit with gDNA Eraser (RR047A, TaKaRa). Quantitative PCR (qPCR) was performed with the One Step SYBR ${ }^{\circledR}$ PrimeScript ${ }^{\mathrm{TM}}$ RTPCR Kit II (Perfect Real Time) (TaKaRa) and a thermocycler (Bio-Rad, USA).

Gene expression was analyzed with quantitative realtime PCR (qPCR) which was conducted in a StepOnePlus Real-Time PCR System (Applied Biosystems, USA). Three antioxidation-related genes (superoxide dismutase (SOD), catalase $(C A T)$, and glutathione peroxidase $(G P X)$ ) were detected with this assay, and the housekeeping genes encoding ribosomal protein L8 (RPL8) and $18 S$ rRNA were used as the internal standards (Table 2) [27, 28]. The primers are shown in Table 2. For $\mathrm{qPCR}$, the $10 \mu \mathrm{L}$ reaction mixture contained $5 \mu \mathrm{L}$ of SYBR Green II PCR Master Mix, $3 \mu \mathrm{L}$ of diethyl-pyrocarbonate-treated water, $0.4 \mu \mathrm{L}$ each of the forward and reverse primers ( $10 \mu \mathrm{mol} / \mathrm{L}), 0.2 \mu \mathrm{L}$ of ROX reference dye (TaKaRa), and $1 \mu \mathrm{L}$ of $\mathrm{cDNA}(100 \mathrm{ng} / \mu \mathrm{L})$. The PCR conditions included initial denaturation for $3 \mathrm{~min}$ at $95^{\circ} \mathrm{C}$, followed by 40 cycles of $95^{\circ} \mathrm{C}$ for $10 \mathrm{~s}$, the melting temperature of the specific primer pairs for $30 \mathrm{~s}, 95^{\circ} \mathrm{C}$ for $10 \mathrm{~s}$, and $72^{\circ} \mathrm{C}$ for $10 \mathrm{~s}$. To distinguish between specific and nonspecific reaction products, a melting curve was constructed at the end of 
TABLE 2: Primers for the variety of genes detected with qPCR.

\begin{tabular}{lccc}
\hline Gene & Abbreviation & Primer sequence $\left(5^{\prime}-3^{\prime}\right)$ & Acc. number \\
\hline Superoxide dismutase 2 & SOD2 & $\begin{array}{l}\text { F: AACCTGAATATTGCAGAGGAGAAGTAC } \\
\text { R: GCAATCTGAGCTGTAACATCTCCTT }\end{array}$ & XM_018565611.1 \\
\hline Catalase & CAT & $\begin{array}{l}\text { F: ATTTCTGGGCTCTGCGTC } \\
\text { R: GGTTCATCCTTGGCGTTA }\end{array}$ & MK561295 \\
\hline Glutathione peroxidase & GSH-Px & $\begin{array}{l}\text { F: TGCCGCTGTTCACCTTCCT } \\
\text { R: AAGTTCCAGGAGATGTCGTTGC }\end{array}$ & MK561296 \\
\hline Ribosomal protein L8 & rpl8 & $\begin{array}{l}\text { F: GCTGTCGACTTCGCAGAAAGGCA } \\
\text { R: ACCTGTAAGGGTCACGGAAGGCA }\end{array}$ & \multirow{2}{*}{ XM_018556352.1 } \\
\hline 18S ribosomal RNA & RNA 18S & $\begin{array}{l}\text { F: CGTTGATTAAGTCCCTGCCCTT } \\
\text { R: GCCGATCCGAGGACCTCACTA }\end{array}$ & AB099628.1 \\
\hline
\end{tabular}

each run. The $2^{-\triangle \Delta C T}$ method was used to calculate the relative changes in mRNA expression from the qPCR results $\left(\Delta \mathrm{CT}=\mathrm{CT}_{\text {target gene }}-\mathrm{CT}_{\text {housekeeping gene, }}, \Delta \Delta \mathrm{CT}=\Delta \mathrm{CT}\right.$ experimental $-\Delta \mathrm{CT}$ control) [29].

2.9. Statistical Analysis. The results are expressed as means \pm standard deviations. The significance of differences was determined with analysis of variance. Each indicator was tested with one-way analysis of variance and a $t$-test. However, prevalence and mortality were analyzed with the Kaplan-Meier method and a log-rank test to determine whether the differences between the groups were significant (SPSS v.20.0, IBM Corp., New York, NY, USA). A value of $P<0.05$ was considered significant, and $P<0.01$ was considered highly significant.

\section{Results}

3.1. Source and Identification of the Strains. The pathogenic strain was originally isolated from $P$. nigromaculatus with wryneck disease and identified. The colonies were round or elliptical, translucent, shiny, and smooth, with a diameter of $1-3 \mathrm{~mm}$. Under a microscope (1000x), the bacteria presented as Gram-negative rods, singly or in pairs $(0.5-1.0 \mu \mathrm{m} \times 1.0-2.5 \mu \mathrm{m})$. The biochemical characteristics of the isolates are shown in Table 3 and are consistent with those of the genus Elizabethkingia. The nearly full-length $16 \mathrm{~S}$ rRNA gene sequences of the isolates were amplified, identified with a BLAST search, and deposited in GenBank (accession numbers: MK333252, MK333253, and MK333254). The three isolates shared the greatest nucleotide homology $(99 \%-100 \%)$ with $E$. miricola (NR_036862.1) (Figure 1). The susceptibilities of the three isolates to antibiotics are shown in Table 4. They were all most sensitive to azithromycin, rifampicin, and florfenicol, followed by enrofloxacin, and were resistant to neomycin, doxycycline, penicillin, cotrimoxazole, cefoxitin, and ampicillin.

3.2. Gross Lesions in E. miricola-Infected P. nigromaculatus. Artificially infected $P$. nigromaculatus displayed symptoms similar to those of wryneck disease in nature. The commonest clinical signs in the sick frogs are side-biased swimming, with the gross lesions of wryneck, side-biased body (Figure 2(a)), edema of the abdomen and thigh (Figure 2(b)), cataract (Figure 2(d)), hemorrhage in the inner thigh skin (Figure 2(f)), congestion of the lung, and hypoplasia of the ovary (Figure 2(c)). X-rays also showed severe rachiocampsis in $P$. nigromaculatus after E. miricola infection (Figure 2(e)).

The prevalence and mortality of E. miricola infection in the frogs were both time and concentration dependent. As the period of challenge time and the challenge concentration increased, both the prevalence of infection and frog mortality increased. The morbidity rates were much higher in the $1 \times 10^{8}, 1 \times 10^{9}$, and $1 \times 10^{10}$ groups than in the control group, by $33.3 \%, 43.3 \%$, and $56.7 \%$, respectively. Elizabethkingia miricola also caused single or multiple concurrent symptoms in the different experimental groups of $P$. nigromaculatus (Figure 2(g)). Wryneck was not a common clinical symptom in the beginning of the disease process in the frogs. Low concentrations of E. miricola predominantly caused mouth redness and body bias, whereas high concentrations were mainly responsible for cataract and wryneck (Figure $2(\mathrm{~h})$ ). The mortality rates also differed across the experimental groups, and mortality was particularly evident in the high-concentration group. In the $1 \times 10^{10}$ group, the bacterium caused death in nearly $70 \%(67.7 \%)$ of $P$. nigromaculatus and in nearly $50 \%$ $(46.7 \%)$ of the $1 \times 10^{9}$ group (Figure $2(\mathrm{i})$ ).

3.3. Systematic Pathology in E. miricola-Infected $P$. nigromaculatus. The frogs showed systemic histopathological changes depending on the concentration of E. miricola with which they were injected. The main target organs were the brain, spinal cord, and eyes. Pelophylax nigromaculatus in the $1 \times 10^{8}$ group showed the earliest pathological changes, followed by the $1 \times 10^{9}$ group and then the $1 \times 10^{10}$ group, whereas $P$. nigromaculatus in the control group showed no obvious histopathological changes (Figure 3(b)). Severe pathological changes were observed in the low-concentration group $\left(1 \times 10^{8}\right)$, which were mainly moderate to severe meningitis, spondylitis, and retinitis. The liver showed moderate edema and local inflammation, the spleen showed a reduction in interstitial cells and hyperplasia of the reticular system, and the kidney interstitium showed 
TABLE 3: Biochemical characteristics of the isolated strains.

\begin{tabular}{|c|c|c|c|c|}
\hline Item & Fy70815 1-3 & E. meningoseptica [2] & E. miricola [3] & C. taichungense [3] \\
\hline Gram staining & - & - & ND & ND \\
\hline Mobility & - & - & ND & ND \\
\hline Catalase & + & + & ND & ND \\
\hline Xylose & - & - & - & $(+)$ \\
\hline Fructose & + & + & + & $\mathrm{ND}$ \\
\hline Esculin & + & + & + & + \\
\hline Indole & $\mathrm{N}$ & $\mathrm{N}$ & $\mathrm{V}$ & $(+)$ \\
\hline Hydrogen sulfide & - & - & $\mathrm{V}$ & - \\
\hline Nitrate & - & - & - & - \\
\hline Ornithine decarboxylase & - & - & ND & $\mathrm{ND}$ \\
\hline Lysine decarboxylase & - & - & ND & ND \\
\hline Arginine decarboxylase & - & ND & ND & ND \\
\hline Arginine double hydrolysis & $\mathrm{N}$ & - & ND & ND \\
\hline Urease & $\mathrm{V}$ & - & ND & ND \\
\hline V-P test & - & - & ND & ND \\
\hline Arabinose & $\mathrm{N}$ & $\mathrm{N}$ & - & - \\
\hline
\end{tabular}

+: positive reaction; -: negative reaction; N: not applicable; V: variable reaction; (+): weak or delayed reaction; ND: not determined.

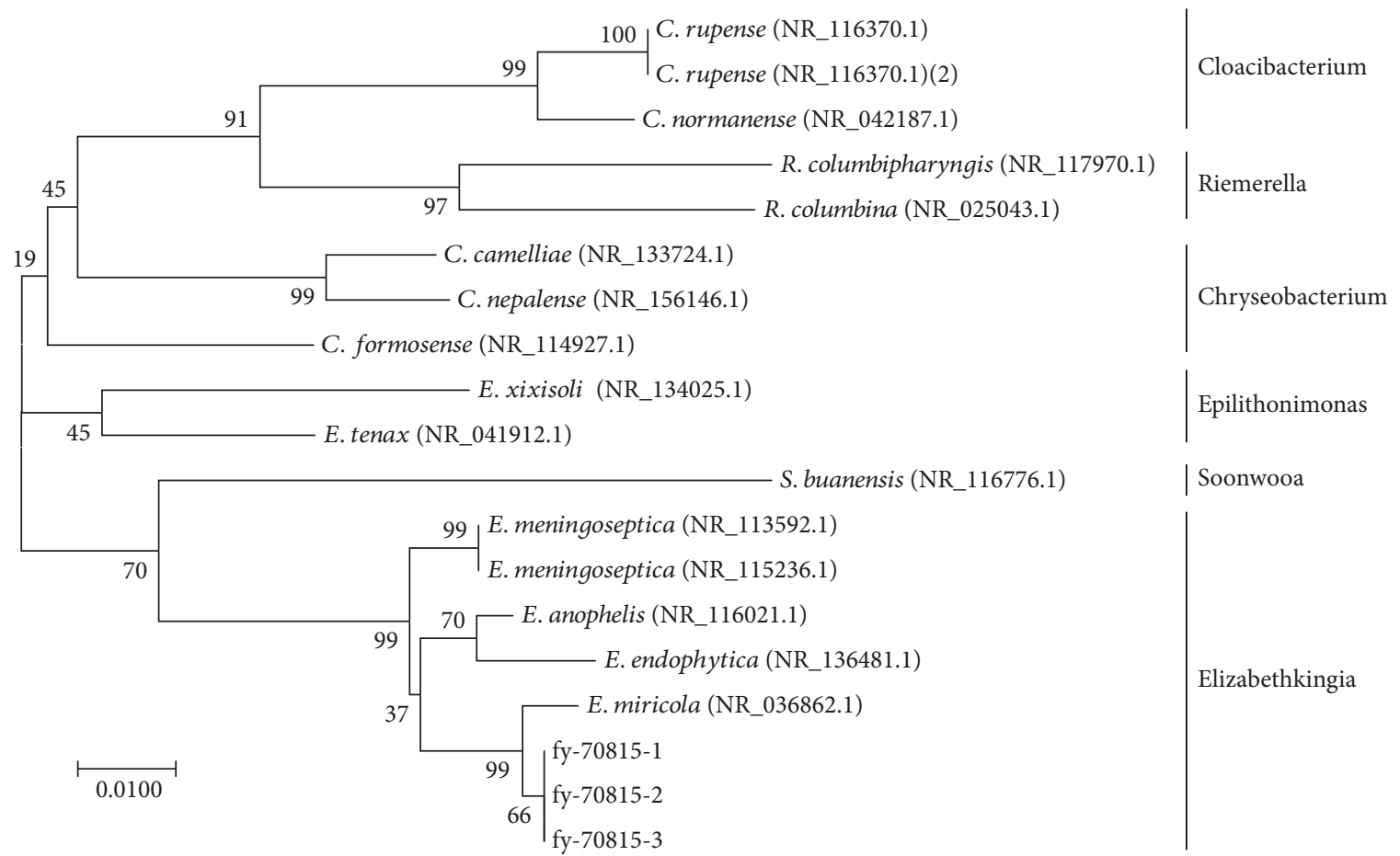

FIGURE 1: The phylogenetic tree was generated with MEGA 7.0 based on an alignment of the 16S rRNA gene sequences of the isolated strains (fy-70815 1-3) and related species.

mild inflammation. Other organs were less affected by the low concentration of E. miricola, with only slight detachment of the gastric mucosal epithelium and mild inflammation in the cardiac chamber. As the concentration of injected bacteria increased $\left(1 \times 10^{9}\right.$ and $\left.1 \times 10^{10}\right)$, the extent of these lesions increased. They were mainly expressed as marked bacterial necrotic brain abscesses and meningoencephalitis, marked bacterial necrotic myelitis, severe retinal necrosis, necrotic hepatitis, necrotic spleen, or necrotic nephritis. The gastrointestinal mucosa was also characterized by marked necrosis and disintegration, with large numbers of bacteria. The heart displayed severe myocarditis and the lung displayed severe necrosis. During the experiment, there were no obvious 
TABLE 4: Sensitivity of the three isolates to antibiotics.

\begin{tabular}{|c|c|c|c|c|c|}
\hline Antibiotic & Resistant (R) & $\begin{array}{c}\text { Standard }(\mathrm{mm}) \\
\text { Moderate }(\mathrm{I})\end{array}$ & Sensitive (S) & $\begin{array}{l}\text { Inhibition } \\
\text { zone (mm) }\end{array}$ & $\begin{array}{c}\text { Sensitivity } \\
\text { range }\end{array}$ \\
\hline Azithromycin & $\leq 13$ & $14-17$ & $\geq 18$ & 20 & S \\
\hline Enrofloxacin & $\leq 14$ & $15-17$ & $\geq 18$ & 15 & I \\
\hline Neomycin & $\leq 12$ & $13-16$ & $\geq 17$ & 11 & $\mathrm{R}$ \\
\hline Doxycycline & $\leq 12$ & $13-15$ & $\geq 16$ & 6 & $\mathrm{R}$ \\
\hline Penicillin & $\leq 19$ & $20-22$ & $\geq 23$ & 6 & $\mathrm{R}$ \\
\hline Rifampicin & $\leq 16$ & $17-19$ & $\geq 20$ & 20 & $S$ \\
\hline Compound neoproxine & $\leq 10$ & $10-16$ & $\geq 16$ & 7 & $\mathrm{R}$ \\
\hline Cefoxitin & $\leq 14$ & $15-17$ & $\geq 18$ & 6 & $\mathrm{R}$ \\
\hline Ampicillin & $\leq 14$ & $15-19$ & $\geq 20$ & 6 & $\mathrm{R}$ \\
\hline Florfenicol & $\leq 12$ & $13-17$ & $\geq 18$ & 25 & S \\
\hline
\end{tabular}

R: resistant; I: moderately sensitive; S: sensitive.

histopathological changes in the muscles and mild inflammation and muscle-fiber necrosis were only observed in the high-concentration groups $\left(1 \times 10^{9}\right.$ and $\left.1 \times 10^{10}\right)$ (Figure 3(a)).

We also observed ultrastructural pathological changes in E. miricola-infected P. nigromaculatus (Figure 3(c)), which were mainly caused by the swelling of the mitochondria and endoplasmic reticulum. Furthermore, E. miricola was detected both intracellularly and in the interstitium of $P$. nigromaculatus.

3.4. Organs Parasitized by E. miricola in P. nigromaculatus. To confirm that the lesions in $P$. nigromaculatus were caused by E. miricola, a PCR assay was conducted with primers specific for the 16S rRNA of E. miricola (Figure 4(a)). When bacteria enter the host, they usually target the organ that best satisfies the requirements for their maintenance and proliferation. Colony counts indicated that the brain was the principal target organ of E. miricola in P. nigromaculatus, because it contained very large amounts of parasitic bacteria. The kidney was the second most important target organ of E. miricola and contained only $\sim 16$ times fewer bacteria than the brain. The bacterial contents in the remaining tissues were much lower than in these two organs (Figure 4(b)). The result indicates that the brain is the favorite parasitic target organ of E. miricola, which may be the cause of meningoencephalitis.

\subsection{Elizabethkingia miricola Inhibits the Antioxidant} Capacity of $P$. nigromaculatus. The antioxidant system plays an important role in eliminating environmental and diseaseinduced oxidative stress. To explain the observed swelling of the mitochondria and the ER, we determined the antioxidant capacity of $P$. nigromaculatus after infection with E. miricola. Our results showed that E. miricola caused a significant reduction in TAC activity in the liver of $P$. nigromaculatus, and as the concentration of $E$. miricola increased, this reduction became more pronounced (Figure 5(a)). When the activity of SOD alone was measured, it was also significantly lower after E. miricola infection than in the control group (Figure 5(b)). These results indicate that E. miricola weakens the antioxidant capacity of the $P$. nigromaculatus liver.
Reduced antioxidant capacity may lead to lipid peroxidation in the frog and cause the deposition of MDA. It is noteworthy that E. miricola infection increased the MDA content of $P$. nigromaculatus, although this increase was not statistically significant (Figure 5(c)).

The transcription of three genes associated with antioxidation (SOD, CAT, and GPX) was also measured. All three genes showed reduced expression after E. miricola challenge, indicating a disordered antioxidation system. Among these genes, $S O D$ transcription was significantly reduced in the $1 \times 10^{9}$ and $1 \times 10^{10}$ groups and GSH-Px transcription in the $1 \times 10^{10}$ group relative to the control group (Figures 5(d) and 5(f)). However, CAT transcription did not differ significantly between the control and experimental groups (Figure 5(e))

\section{Discussion}

Elizabethkingia is a new genus of bacteria, and most of its species are highly pathogenic to immunocompromised humans and animals [6-8]. Among these species, some subtypes of E. meningoseptica, E. miricola, and E. anopheles can cause meningitis in humans or animals and cause incurable disease and death in large numbers of patients $[6,14]$. The isolation of E. miricola from $P$. nigromaculatus with wryneck disease in the present study has undoubtedly extended our understanding of the pathogenic spectrum of the genus Elizabethkingia. Because the lesions caused by E. miricola in $P$. nigromaculatus were similar to those caused by other Elizabethkingia spp. in humans, $P$. nigromaculatus may have utility as a model organism in the prevention and treatment of Elizabethkingia-induced human diseases. In this study, the systematic pathology of and oxidative damage caused by $E$. miricola in $P$. nigromaculatus were investigated with retrogressive infection in the laboratory. Our results show that E. miricola is a bacterium that mainly parasitizes the host brain and that the neurogenic organs are its main targets. The main damage caused was severe bacterial necrotic inflammation. The dysregulation of the P. nigromaculatus antioxidant system during infection may have aggravated these pathological processes (Figure 6). Our results provide 


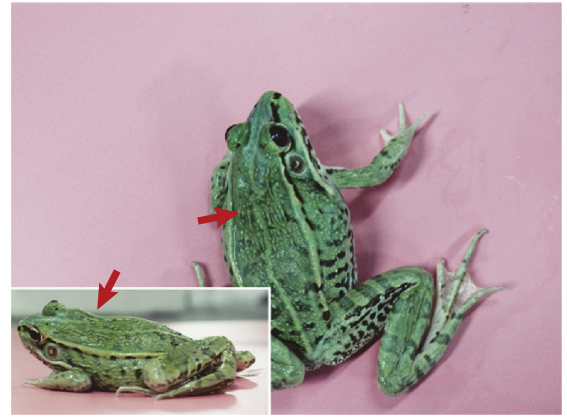

(a)
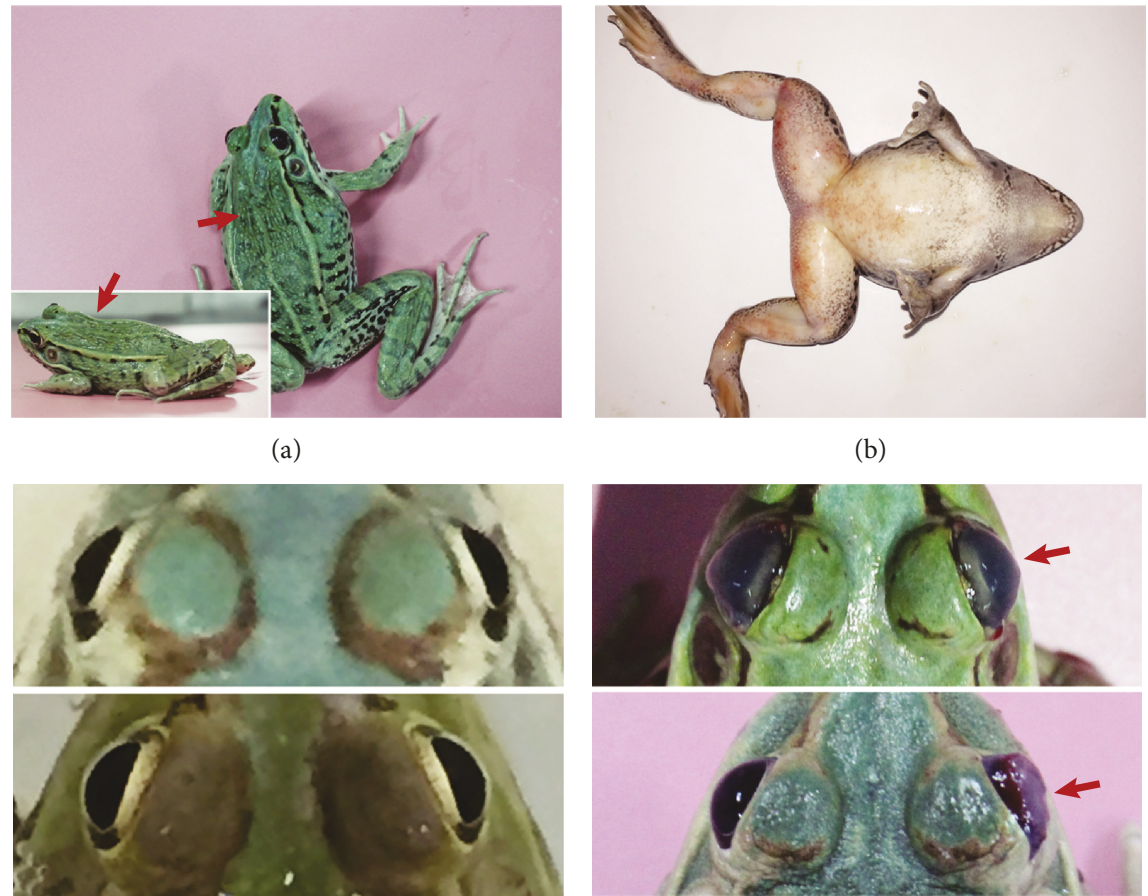

(b)
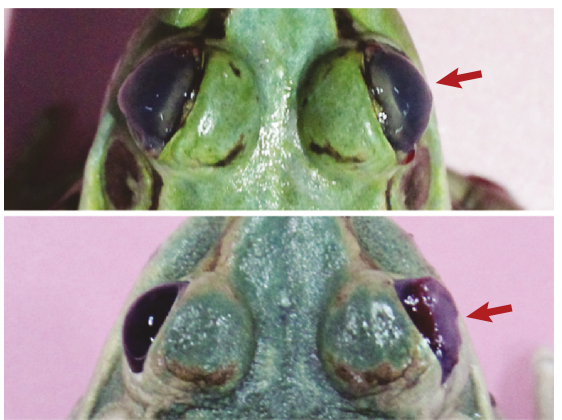

(d)
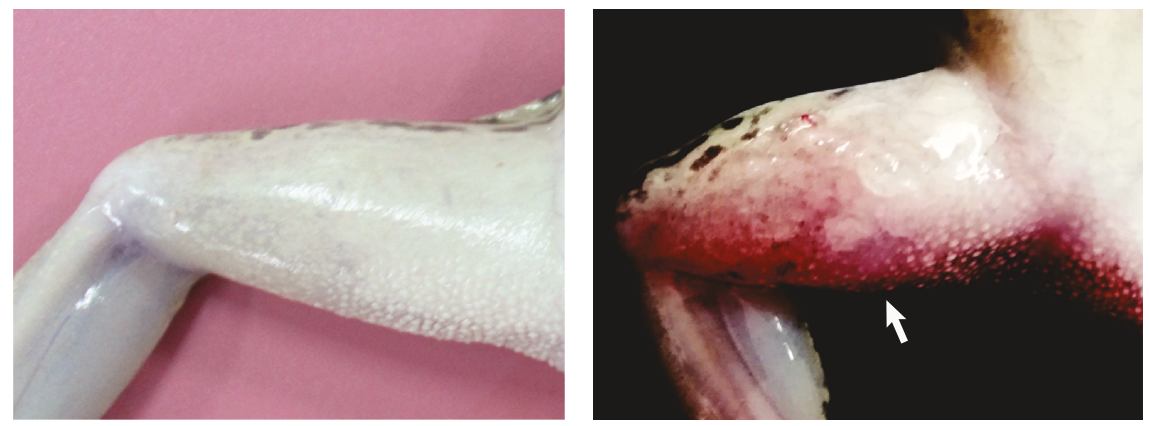

(f)

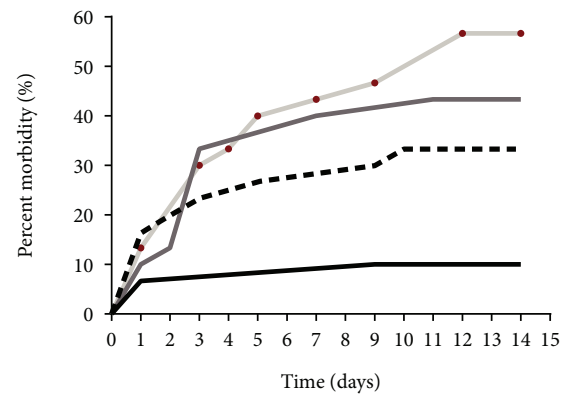

$$
\begin{aligned}
& \text { - Control } \\
& \text {--- } \begin{array}{l}
1 \times 10^{8} \\
(P<0.050 ; \mathrm{HR}=0.2873)
\end{array} \\
& \text { - } 1 \times 10^{9} \\
& (P<0.010 ; \mathrm{HR}=0.2287) \\
& \text { - } 1 \times 10^{10} \\
& (P<0.001 ; \mathrm{HR}=0.1740)
\end{aligned}
$$

(g)

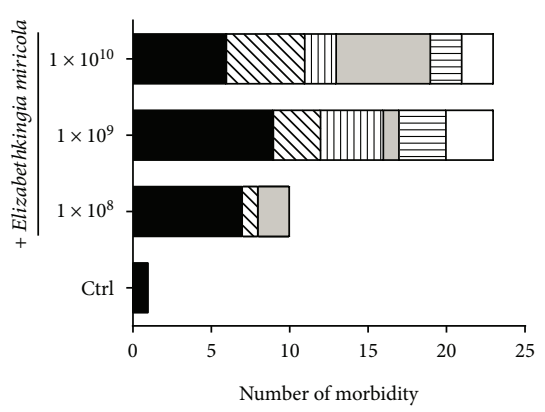

\begin{tabular}{lll} 
Body bias & Red leg \\
\hline Epidermis ulceration & Cataract \\
Wryneck & Red lips
\end{tabular}

(h)

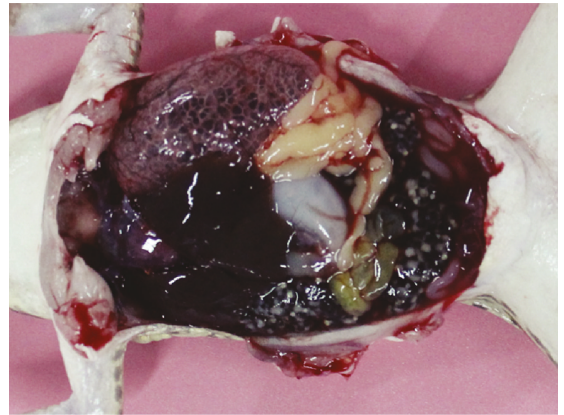

(c)
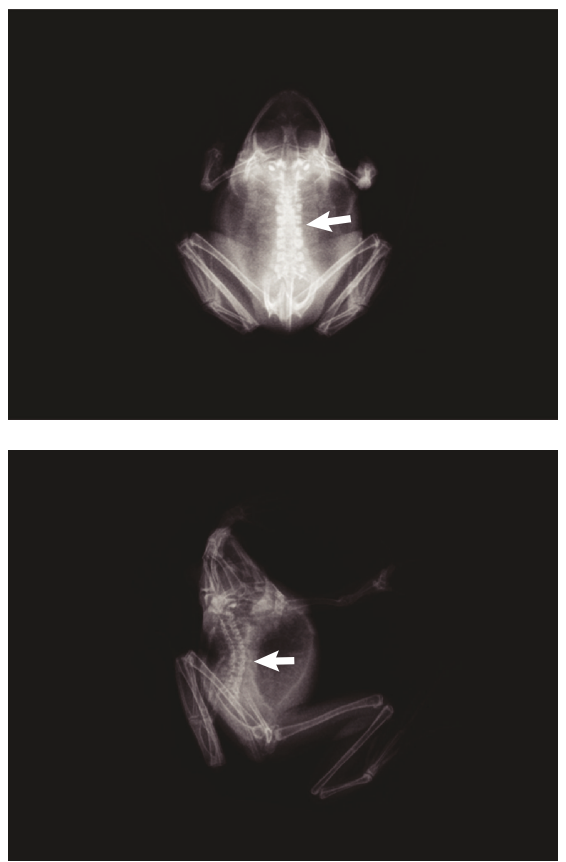

(e)

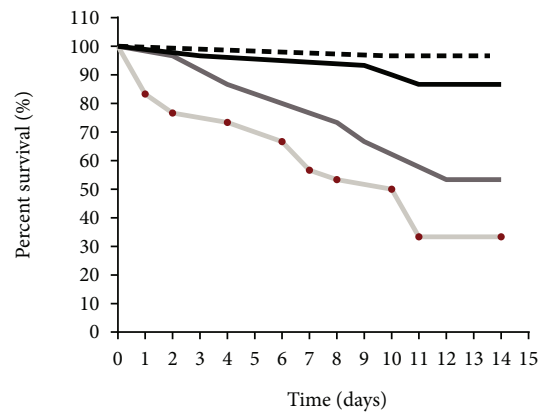

$$
\begin{array}{ll}
\text { Control } \\
-\mathbf{- -} & 1 \times 10^{8} \\
& (P<0.050 ; \mathrm{HR}=3.5200) \\
& 1 \times 10^{9} \\
& (P<0.010 ; \mathrm{HR}=0.2615) \\
-\quad & 1 \times 10^{10} \\
& (P<0.001 ; \mathrm{HR}=0.1583)
\end{array}
$$

(i)

Figure 2: Gross lesions in E. miricola-infected P. nigromaculatus. (a) Head biased to one side; (b) abdomen and thigh swelling; (c) congestion of the lungs, hypoplasia of the ovary; (d) left: normal eyes and right: cataracts; (e) top: normal spine and bottom: rachiocampsis; (f) left: normal thigh and right: redness on frog thigh. (g) Morbidity (\%) among P. nigromaculatus during E. miricola infection. (h) Symptom types in frogs of different groups. (i) Survival (\%) of $P$. nigromaculatus during E. miricola infection. $P$ values and hazard ratios (HRs) are relative to the control group. 

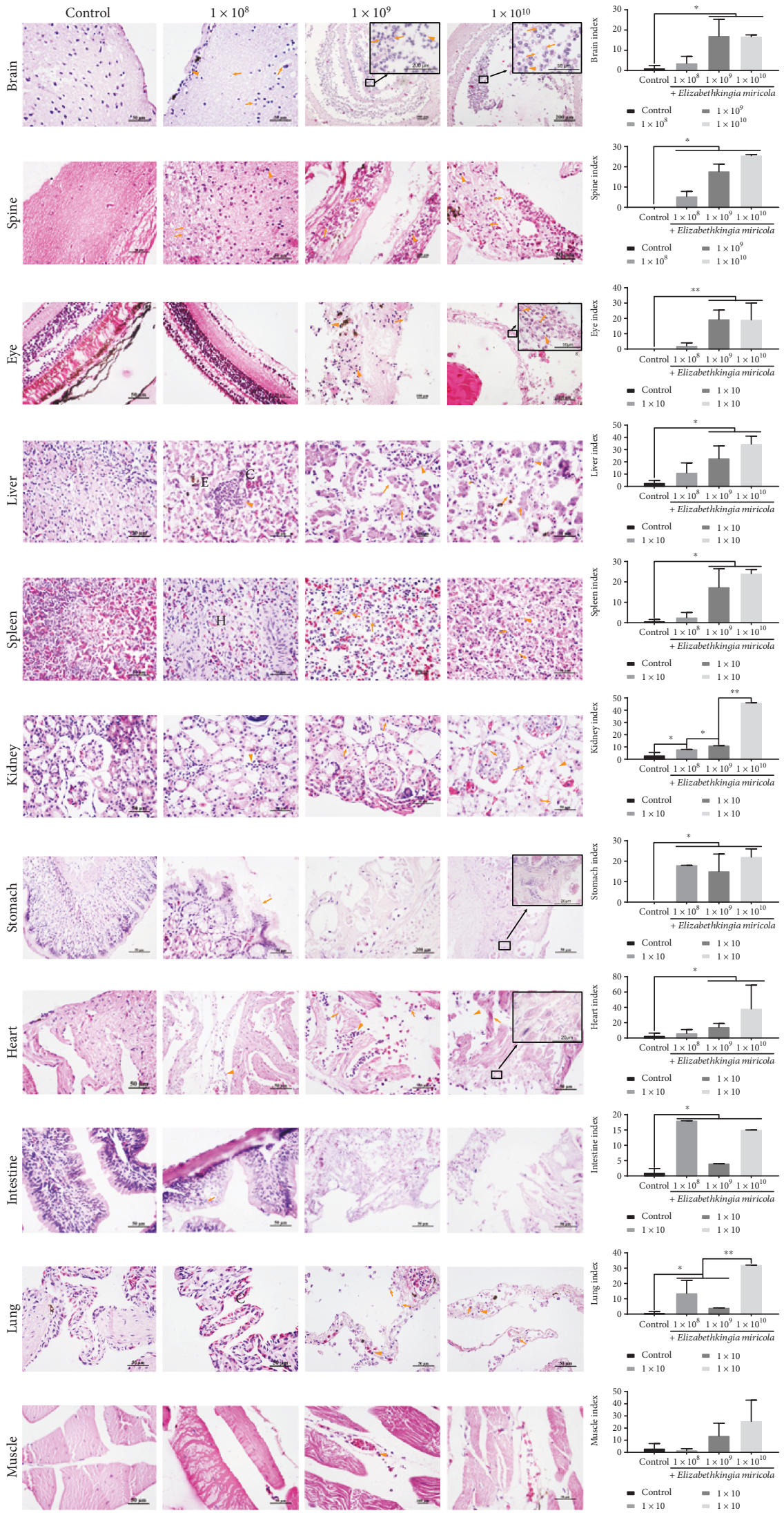

(a)

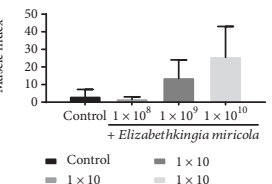

FIgURE 3: Continued. 


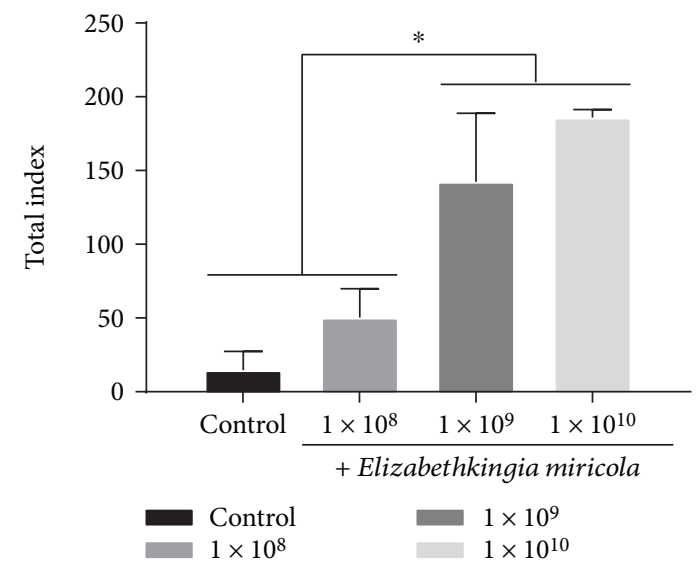

(b)

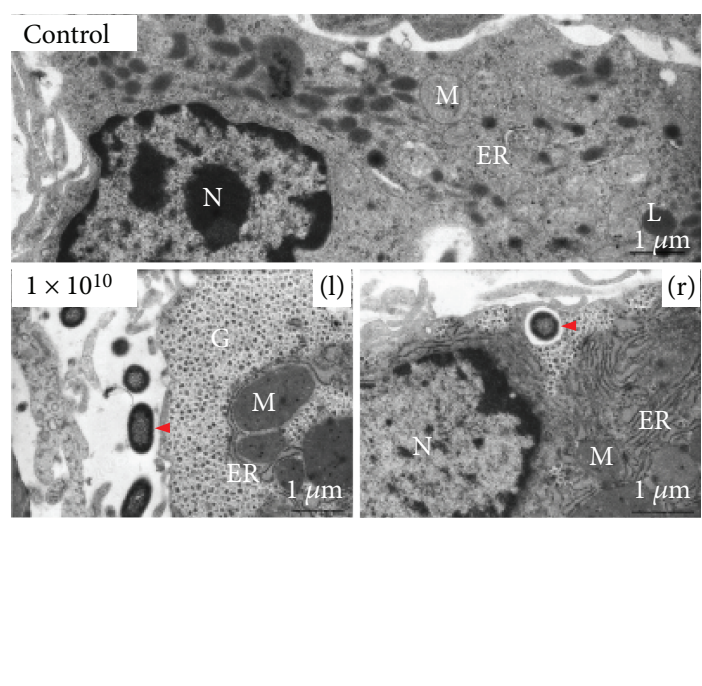

(c)

Figure 3: Dynamic systematic pathology of P. nigromaculatus caused by E. miricola infection. (a) Histopathological changes induced by E. miricola ( $\mathbf{\Delta}$ : inflammatory cell infiltration; $\rightarrow$ : necrotic cells; E: edema; C: congestion; H: hyperplasia). (b) Overall health status (total index) of frogs in different groups, based on histopathological lesions. (c) Ultrastructural changes induced by E. miricola (N: nucleus; M: mitochondria; ER: endoplasmic reticulum; L: lysosome). $P<0.05$ or ${ }^{* *} P<001$ represents a significant difference or highly significant difference between groups. Dynamic systematic pathology of $P$. nigromaculatus caused by E. miricola infection.

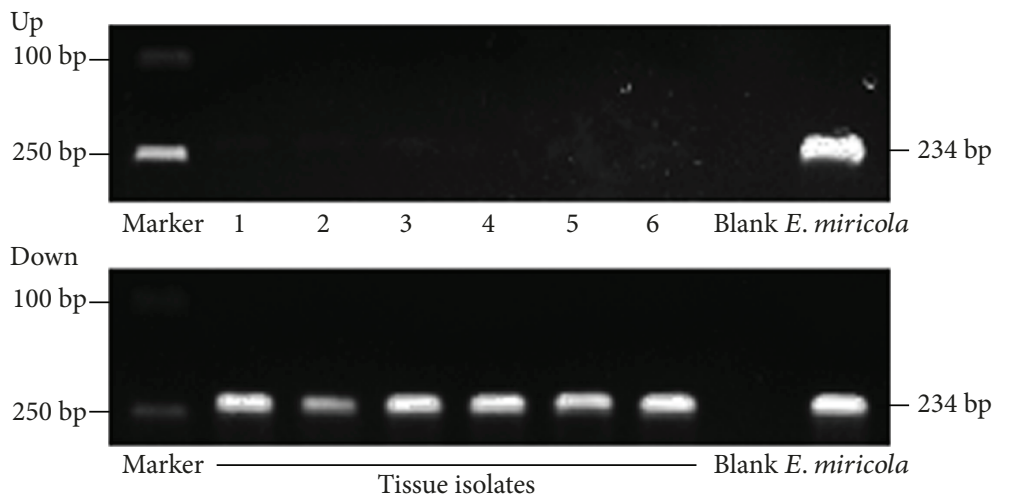

(a)

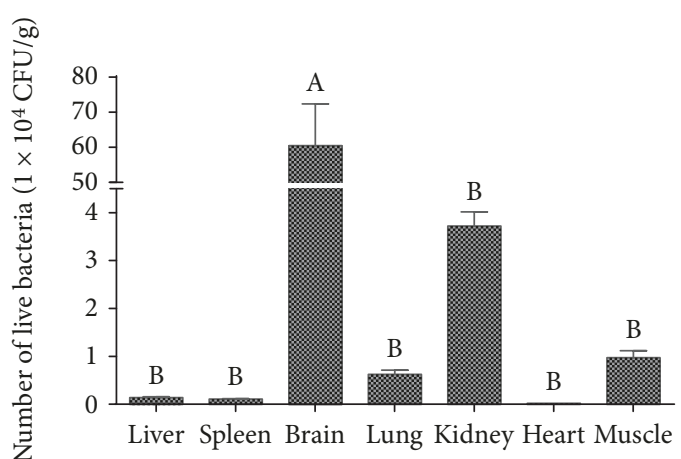

(b)

FIgURE 4: Organs parasitized by E. miricola in P. nigromaculatus. (a) PCR identification of bacteria in diseased frogs. Up: identification of $E$. miricola with 16S-rRNA-specific primers; 1: Escherichia coli; 2: Klebsiella pneumoniae; 3: Aeromonas veronii; 4: A. hydrophila; 5: Pseudomonas plecoglossicida; 6: Stenotrophomonas sp. Down: confirmation of strains of P. nigromaculatus in the experimental group. (b) Tissue distribution of E. miricola in P. nigromaculatus. Different lowercase letters indicate significant differences between groups.

a preliminary reference for the study and treatment of Elizabethkingia-induced neurological diseases.

In this study, we found that the brain is the primary target organ of E. miricola and P. nigromaculatus showed typical neurological symptoms, including wryneck, body bias, and cataract. Histopathology further clarified the clinical lesions caused by this bacterium, which mainly manifested as typical severe bacterial purulent meningoencephalitis, severe bacterial necrotic myelitis, and severe bacterial necrotic retinitis. Similar results have been demonstrated in humans. Previous studies have reported that Elizabethkingia spp. are often associated with meningitis and spondylitis in newborns and immunocompromised adults [30] and that Elizabethkingia spp. primarily affects neurogenic organs. However, these bac- teria can also cause systemic infections. We found small numbers of bacteria distributed in the muscle, lung, spleen, and liver, with different degrees of histopathological disturbance. There was obvious bacterial necrotic inflammation in the liver, spleen, kidney, heart, and gastrointestinal tract. Unfortunately, we did not count the bacteria in the gastrointestinal tract to avoid bacterial contamination. However, the gastrointestinal tract was one of the main target organs, showing large numbers of rod-shaped bacteria in the lamina propria and submucosa, accompanied by severe, histopathologically detected, bacterial necrotic gastroenteritis. These findings indicate that infection with $E$. miricola causes multiorgan damage in P. nigromaculatus and that these symptoms are quite similar to those observed during the infection of 


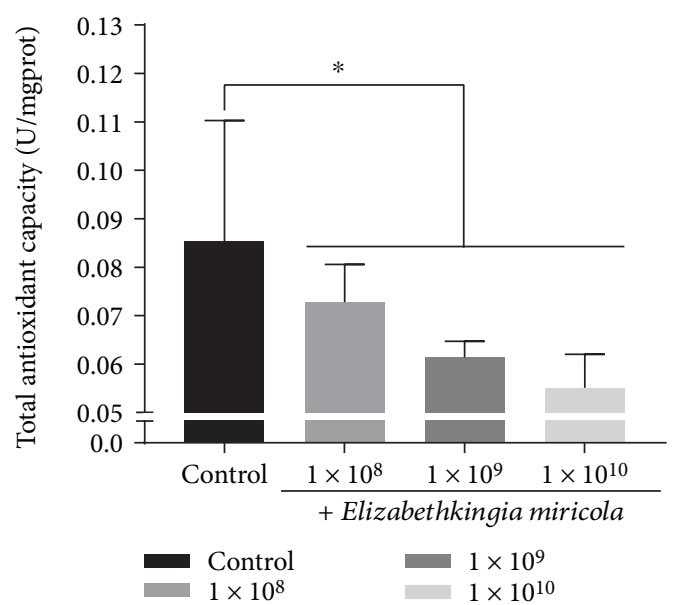

(a)

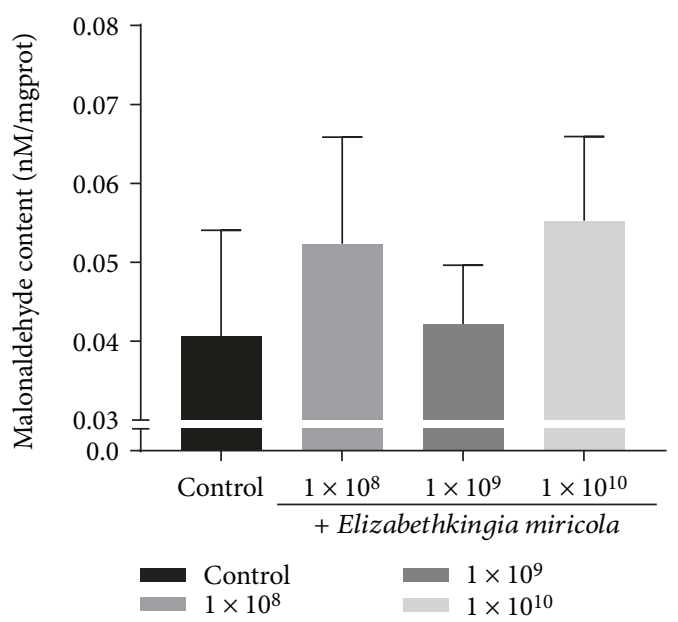

(c)

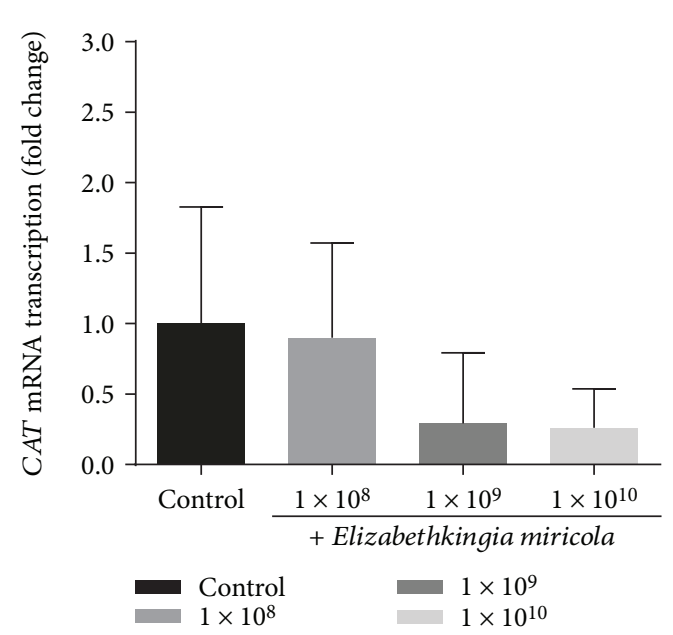

(e)

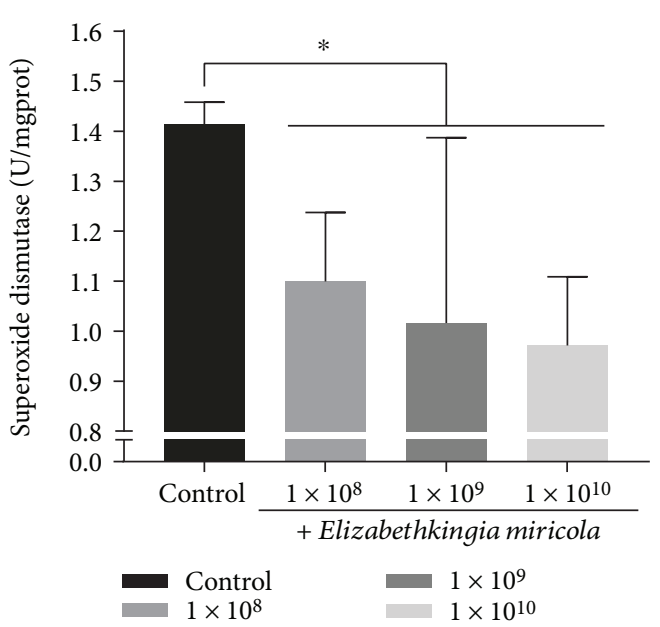

(b)

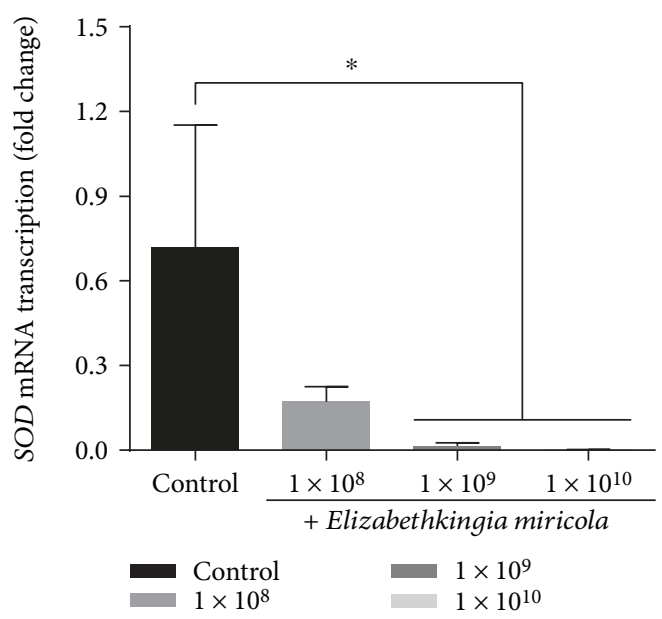

(d)

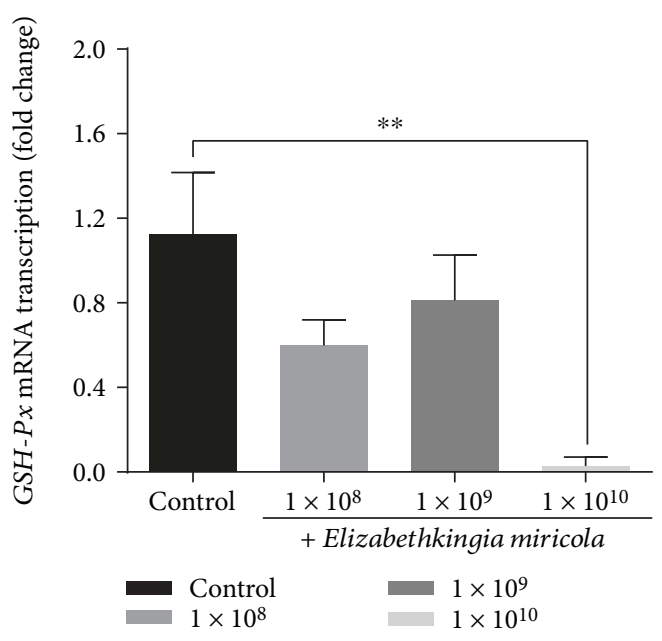

(f)

FIGURE 5: Antioxidation capacity of $P$. nigromaculatus in different groups. (a-c) Assessment of TAC, SOD, and MDA in P. nigromaculatus in different groups. (d-f) Expression of SOD, CAT, and GPX mRNAs in P. nigromaculatus. $P<0.05$ or ${ }^{* *} P<001$ represents a significant difference or highly significant difference between groups. 


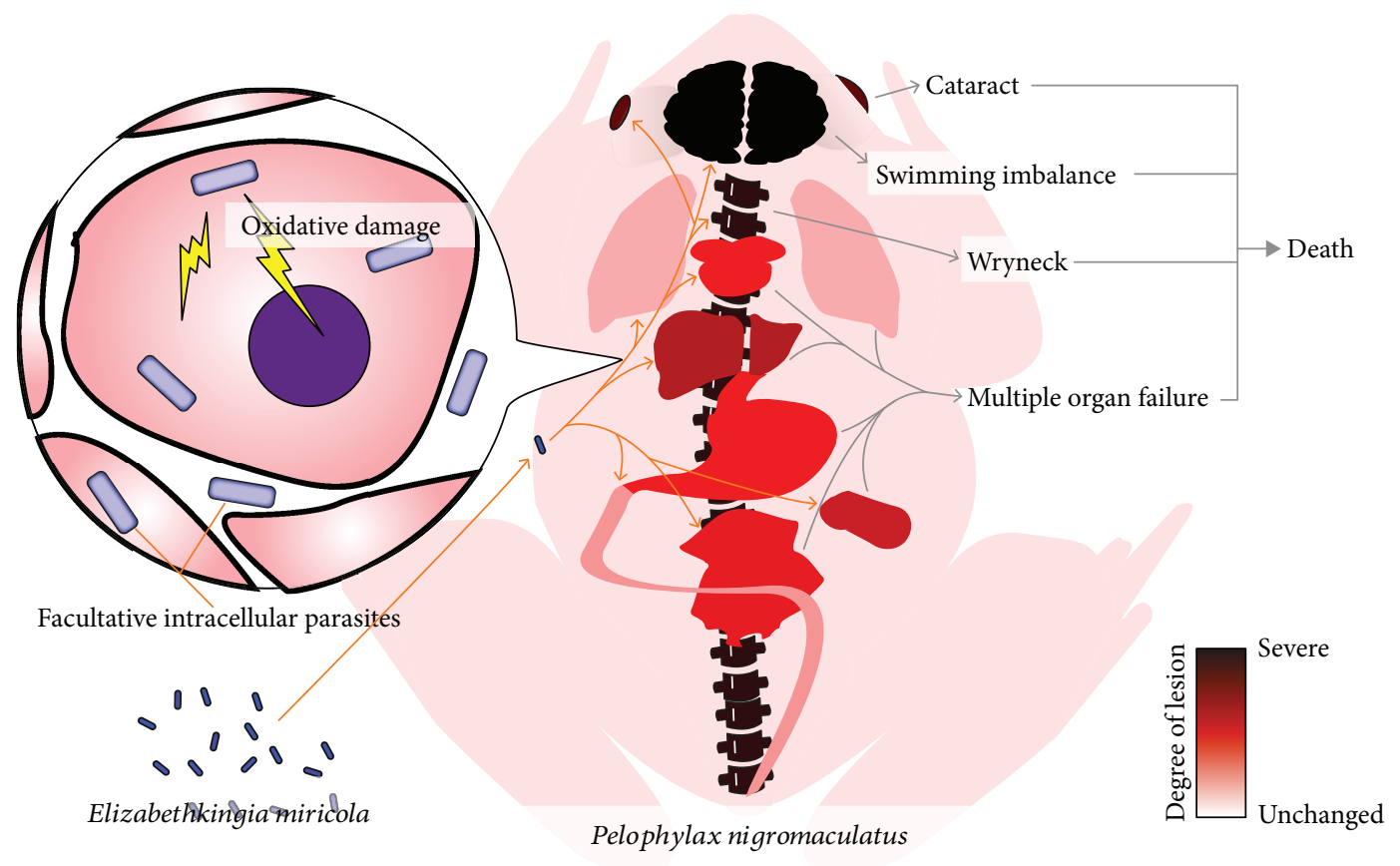

Figure 6: Systemic infection model of E. miricola against $P$. nigromaculatus.

humans by Elizabethkingia spp. Elizabethkingia spp. reportedly causing a variety of diseases, including pneumonia, bacteremia, sepsis, endocarditis, abdominal abscess, sinusitis, bronchitis, epididymitis, and dialysis-related peritonitis in immunocompromised adults [31] and bacterial necrotic inflammation may be a common pathological condition caused by Elizabethkingia spp.

The antioxidant system plays an important role in eliminating environmental and disease-induced oxidative stress [32]. An outbreak of disease often disrupts the antioxidant system, generates numerous free radicals, and causes oxidative damage to the body. The swelling of the mitochondria and ER suggests that E. miricola causes oxidative stress in P. nigromaculatus [33], which often results in mitochondrial stress and the unfolded protein response and in turn to removes intracellular free radicals [34]. The detection of antioxidants and the increased expression of antioxidation-associated genes indicated that the antioxidant capacity of $P$. nigromaculatus was compromised during E. miricola infection. These results indicate that an animal may gradually lose its antioxidant system after it is infected by Elizabethkingia spp., which may further aggravate its disease state.

Previous studies have reported that Elizabethkingia spp., which are Gram-negative bacteria, show excellent resistance to antibiotics, which may explain why patients are difficult to cure of these infections [35-37]. We found that E. miricola mainly parasitizes the neurological organs, such as the brain. It can live outside the intercellular matrix, and a few bacteria may be able to enter the cytoplasm. Most intracellular bacteria, such as Staphylococcus aureus [38] and Mycobacterium tuberculosis [39], are difficult to treat with drugs because they are protected by the cell membrane. This may also explain why the drug treatment of the human meningitis caused by
Elizabethkingia spp. infection is ineffective. Although some antibiotics may be highly toxic to these bacteria, their poor liposolubility may inhibit their entry into the cell [40]. Therefore, drugs that are more liposoluble and that are more ready to penetrate the blood-brain barrier should offer more effective therapeutic options for Elizabethkingia spp.-induced diseases.

\section{Conclusions}

Genus Elizabethkingia is a new type of human opportunistic pathogen, commonly infecting newborns and immunocompromised adults, leading to meningitis, brain abscess, and many other conditions. Cases infected with Elizabethkingia usually lead to more than 50\% mortality, causing serious public safety problems. This study established the E. miricola infection of the $P$. nigromaculatus model, to understand the pathological damage of Elizabethkingia to animals. We found that E. miricola is a bacterium that could be facultative intracellularly parasitic in the host, which could cause systemic damage to the $P$. nigromaculatus by producing oxidative stress. E. miricola prefers to be parasitic in nerve tissue, causing significant neuronal necroinflammation in the brain, spine, and eyeballs (Figure 6). The present study helps to further understand the damage to the host of Elizabethkingia spp. Also, P. nigromaculatus may become a candidate animal disease model of Elizabethkingia spp. infection in humans.

\section{Data Availability}

The data used to support the findings of this study are available from the corresponding author upon request. 


\section{Conflicts of Interest}

The authors declare that they have no conflict of interests.

\section{Authors' Contributions}

All authors read and approved the final manuscript. Xiaoli Huang, Yang Feng, Hong Tang, and Guanqing Xiong contributed equally to this work.

\section{Acknowledgments}

This research was supported by grants from the double support plan of Sichuan Agricultural University (no. 03571775), the National Science Foundation (no. 31401488), and the Applied Basic Research from Technological Office of Sichuan Province (nos. 2015JY0206 and 19YYJC2725). We thank all authors for stimulating discussions and support and thank the International Science Editing for their professional English language editing services.

\section{References}

[1] K. K. Kim, M. K. Kim, J. H. Lim, H. Y. Park, and S. T. Lee, "Transfer of Chryseobacterium meningosepticum and Chryseobacterium miricola to Elizabethkingia gen. nov. as Elizabethkingia meningoseptica comb. nov. and Elizabethkingia miricola comb. nov," International Journal of Systematic and Evolutionary Microbiology, vol. 55, no. 3, pp. 1287-1293, 2005.

[2] E. O. King, "Studies on a group of previously unclassified bacteria associated with meningitis in infants," American Journal of Clinical Pathology, vol. 31, no. 3, pp. 241-247, 1959.

[3] Y. Li, Y. Kawamura, N. Fujiwara et al., "Chryseobacterium miricola sp nov., a novel species isolated from condensation water of space station Mir," Systematic and Applied Microbiology, vol. 26, no. 4, pp. 523-528, 2003.

[4] P. Kämpfer, H. Matthews, S. P. Glaeser, K. Martin, N. Lodders, and I. Faye, "Elizabethkingia anophelis sp. nov., isolated from the midgut of the mosquito Anopheles gambiae," International Journal of Systematic and Evolutionary Microbiology, vol. 61, no. 11, pp. 2670-2675, 2011.

[5] S. P. Glaeser, P. Kämpfer, H.-J. Busse, and J. A. McInroy, "Elizabethkingia endophytica sp. nov., isolated from Zea mays and emended description of Elizabethkingia anophelis (Kämpfer et al. 2011)," International Journal of Systematic and Evolutionary Microbiology, vol. 65, no. 7, pp. 2187-2193, 2015.

[6] M. Z. Amer, M. Bandey, A. Bukhari, and D. Nemenqani, "Neonatal meningitis caused by Elizabethkingia meningoseptica in Saudi Arabia," Journal of Infection in Developing Countries, vol. 5, no. 10, pp. 745-747, 2011.

[7] T. Frank, J. C. Gody, L. B. L. Nguyen et al., "First case of Elizabethkingia anophelis meningitis in the Central African Republic," Lancet, vol. 381, no. 9880, pp. 1876-1876, 2013.

[8] F. Frost and D. Nazareth, "Case report: first report of Elizabethkingia miricola infection in a patient with cystic fibrosis," F1000 Research, vol. 7, p. 440, 2018.

[9] S. S. Hayek, T. T. Abd, S. K. Cribbs et al., "Rare Elizabethkingia meningosepticum meningitis case in an immunocompetent adult," Emerging Microbes \& Infections, vol. 2, no. 1, pp. 1-4, 2019.

[10] L. S. P. Moore, D. S. Owens, A. Jepson et al., "Waterborne Elizabethkingia meningoseptica in adult critical care," Emerging Infectious Diseases, vol. 22, no. 1, pp. 9-17, 2016.

[11] G. Montrucchio, S. Corcione, M. Vaj et al., "First case of $E$. meningoseptica in Italy in a patient with necrotic hemorrhagic pancreatitis," Infection, vol. 46, no. 1, pp. 123-125, 2018.

[12] S. K. P. Lau, A. K. L. Wu, J. L. L. Teng et al., "Evidence for Elizabethkingia anophelis transmission from mother to infant, Hong Kong," Emerging Infectious Diseases, vol. 21, no. 2, pp. 232-241, 2015.

[13] V. Tak, P. Mathur, P. Varghese, and M. C. Misra, "Elizabethkingia meningoseptica: an emerging pathogen causing meningitis in a hospitalized adult trauma patient," Indian Journal of Medical Microbiology, vol. 31, no. 3, pp. 293-295, 2013.

[14] J. T. Kirby, H. S. Sader, T. R. Walsh, and R. N. Jones, “Antimicrobial susceptibility and epidemiology of a worldwide collection of Chryseobacterium spp: report from the SENTRY Antimicrobial Surveillance Program (1997-2001)," Journal of Clinical Microbiology, vol. 42, no. 1, pp. 445-448, 2004.

[15] E. J. Dziuban, J. L. Franks, M. So, G. Peacock, and D. D. Blaney, "Elizabethkingia in children: a comprehensive review of symptomatic cases reported from 1944 to 2017," Clinical Infectious Diseases, vol. 67, no. 1, pp. 144-149, 2018.

[16] I. K. Gokce, M. Y. Oncel, R. Ozdemir et al., "Trimethoprimsulfamethoxazole treatment for meningitis owing to multidrug-resistant Elizabethkingia meningoseptica in an extremely low-birthweight, premature infant," Paediatrics and International Child Health, vol. 32, no. 3, pp. 177-179, 2013.

[17] E. Snesrud, P. McGann, E. Walsh et al., "Clinical and genomic features of the first cases of Elizabethkingia anophelis infection in New York, including the first case in a healthy infant without previous nosocomial exposure," Journal of the Pediatric Infectious Diseases Society, vol. 8, no. 3, pp. 269-271, 2019.

[18] A. Tlemsani, S. Kermani, F. Djedjig, S. Bouheraoua, N. Benamrouche, and H. Tali-maamar, "A case of community acquired Elisabethkingia meningoseptica meningitis in an infant," Médecine et Maladies Infectieuses, vol. 45, no. 1-2, pp. 51-52, 2015.

[19] M. Ceyhan and M. Celik, "Elizabethkingia meningosepticum (Chryseobacterium meningosepticum) infections in children," International Journal of Pediatrics, vol. 2011, Article ID 215237, 7 pages, 2011.

[20] S. L. Green, D. M. Bouley, R. J. Tolwani et al., "Identification and management of an outbreak of Flavobacterium meningosepticum infection in a colony of South African clawed frogs (Xenopus laevis)," Journal of the American Veterinary Medical Association, vol. 214, no. 12, pp. 1792-1793, 1999.

[21] J. Ransangan, N. Zainuri, T. M. Lal, B. Jintoni, and V. S. Chung, "Identification of Elizabethkingia meningoseptica from American bullfrog (Rana catesbiana) farmed in Sabah, Malaysia using PCR method and future management of outbreak," Malaysian Journal of Microbiology, vol. 9, no. 1, pp. 769-776, 2013.

[22] F. R. Taylor, R. C. Simmonds, and D. G. Loeffler, "Isolation of Flavobacterium meningosepticum in a colony of leopard frogs (Rana pipiens)," Laboratory Animal Science, vol. 43, no. 1, p. 105, 1993. 
[23] Z. Y. Xie, Y. C. Zhou, S. F. Wang et al., "First isolation and identification of Elizabethkingia meningoseptica from cultured tiger frog, Rana tigerina rugulosa," Veterinary Microbiology, vol. 138, no. 1-2, pp. 140-144, 2009.

[24] R. Hu, J. Yuan, Y. Meng, Z. Wang, and Z. Gu, "Pathogenic Elizabethkingia miricola infection in cultured black-spotted frogs, China, 2016," Emerging Infectious Diseases, vol. 23, no. 12, pp. 2055-2059, 2017.

[25] X. P. Lei, G. Yi, K. Y. Wang et al., "Elizabethkingia miricola infection in Chinese spiny frog (Quasipaa spinosa)," Transboundary and Emerging Diseases, vol. 66, no. 2, pp. 10491053, 2019.

[26] D. Bernet, H. Schmidt, W. Meier, P. Burkhardt-Holm, and T. Wahli, "Histopathology in fish: proposal for a protocol to assess aquatic pollution," Journal of Fish Diseases, vol. 22, no. 1, pp. 25-34, 2010.

[27] J. Chen, T. Meng, Y. Li, K. Gao, and Z. Qin, "Effects of triclosan on gonadal differentiation and development in the frog Pelophylax nigromaculatus," Journal of Environmental Sciences, vol. 64, no. 2, pp. 157-165, 2018.

[28] X. Jia, Z. Liu, X. Lu et al., "Effects of MCLR exposure on sex hormone synthesis and reproduction-related genes expression of testis in male Rana nigromaculata," Environmental Pollution, vol. 236, pp. 12-20, 2018.

[29] K. J. Livak and T. D. Schmittgen, "Analysis of relative gene expression data using real-time quantitative PCR and the 2 $\Delta \Delta \mathrm{CT}$ method," Methods, vol. 25, no. 4, pp. 402-408, 2001.

[30] K. C. Bloch, R. Nadarajah, and R. Jacobs, "Chryseobacterium meningosepticum: an emerging pathogen among immunocompromised adults. Report of 6 cases and literature review," Medicine, vol. 76, no. 1, pp. 30-41, 1997.

[31] S. H. Jung, B. Lee, A. E. Mirrakhimov, and N. Hussain, "Septic shock caused by Elizabethkingia meningoseptica: a case report and review of literature," Case Reports in Medicine, vol. 2013, no. apr03 1, Article ID bcr2013009066, 2013.

[32] D. M. Monti, M. M. Rigano, S. M. Monti, and H. S. Peixoto, "Role of antioxidants in the protection from aging-related diseases," Oxidative Medicine and Cellular Longevity, vol. 2019, Article ID 7450693, 2 pages, 2019.

[33] M. L.-H. Huang, S. Chiang, D. S. Kalinowski, D. H. Bae, S. Sahni, and D. R. Richardson, "The role of the antioxidant response in mitochondrial dysfunction in degenerative diseases: cross-talk between antioxidant defense, autophagy, and apoptosis," Oxidative Medicine and Cellular Longevity, vol. 2019, Article ID 6392763, 26 pages, 2019.

[34] J. D. Malhotra and R. J. Kaufman, "ER stress and its functional link to mitochondria: role in cell survival and death," Cold Spring Harbor Perspectives in Biology, vol. 3, no. 9, article a004424, 2011.

[35] Z. Zong, "Elizabethkingia meningoseptica as an unusual pathogen causing healthcare-associated bacteriuria," Internal Medicine, vol. 53, no. 16, pp. 1877-1879, 2014.

[36] S. S. Jean, W. S. Lee, F. L. Chen, T. Y. Ou, and P. R. Hsueh, "Elizabethkingia meningoseptica: an important emerging pathogen causing healthcare-associated infections," Journal of Hospital Infection, vol. 86, no. 4, pp. 244-249, 2014.

[37] V. V. Shailaja, A. K. Reddy, M. Alimelu, and L. N. R. Sadanand, "Neonatal meningitis by multidrug resistant Elizabethkingia meningosepticum identified by $16 \mathrm{~s}$ ribosomal RNA gene sequencing," International Journal of Pediatrics, vol. 2014, Article ID 918907, 4 pages, 2014.
[38] R. J. Yancey, M. S. Sanchez, and C. W. Ford, "Activity of antibiotics against Staphylococcus aureus within polymorphonuclear neutrophils," European Journal of Clinical Microbiology \& Infectious Diseases, vol. 10, no. 2, pp. 107-113, 1991.

[39] A. Fietta, M. Morosini, and A. Cascina, "Effects of continuous or pulsed exposure to rifabutin and sparfloxacin on the intracellular growth of Staphylococcus aureus and Mycobacterium tuberculosis," Journal of Chemotherapy, vol. 13, no. 2, pp. 167-175, 2001.

[40] P. M. Tulkens, "Intracellular distribution and activity of antibiotics," European Journal of Clinical Microbiology \& Infectious Diseases, vol. 10, no. 2, pp. 100-106, 1991. 


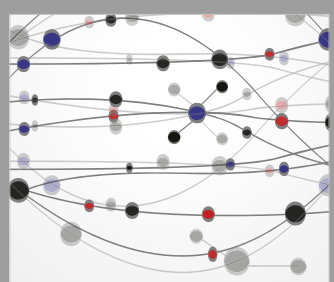

The Scientific World Journal
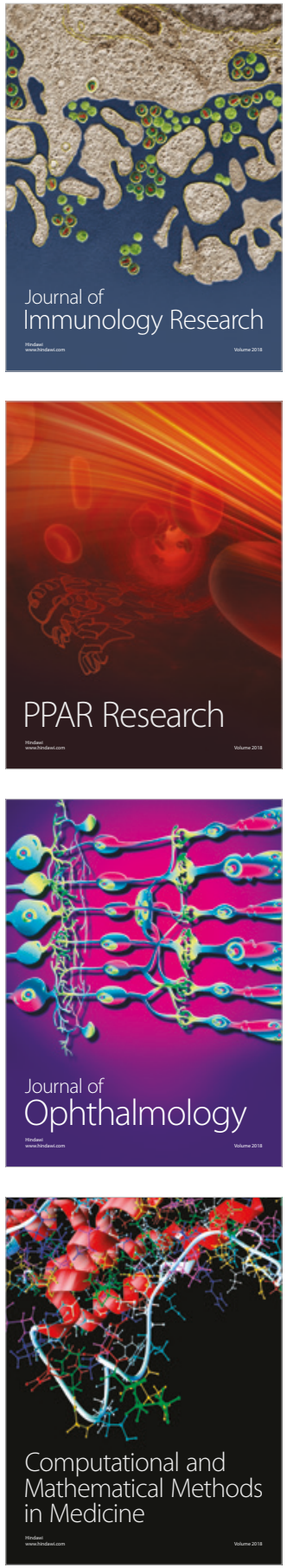

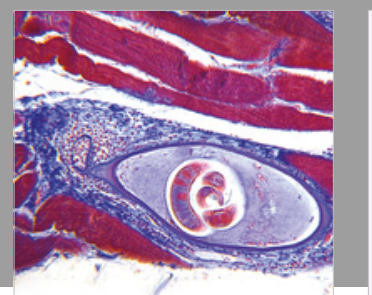

Gastroenterology Research and Practice

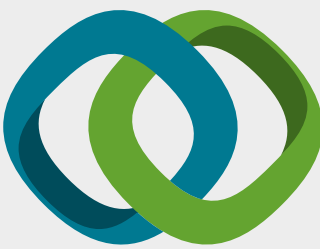

\section{Hindawi}

Submit your manuscripts at

www.hindawi.com
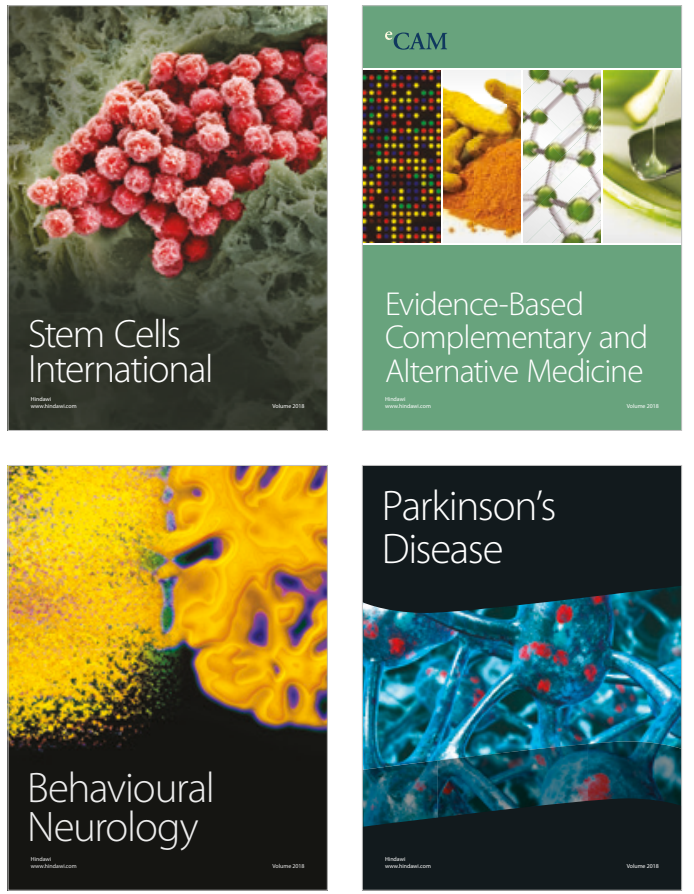

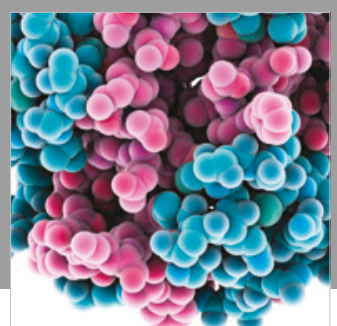

ournal of

Diabetes Research

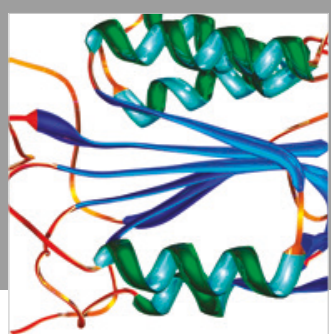

Disease Markers
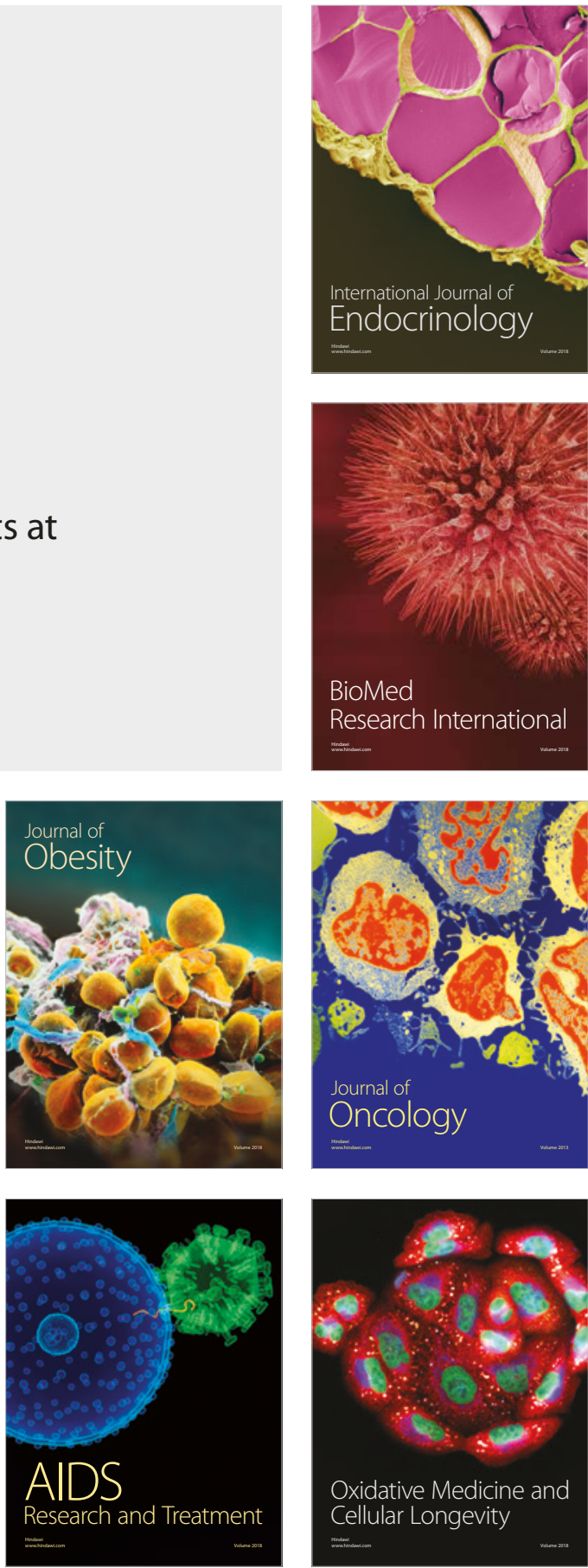